\title{
The role of soil moisture content on maize (Zea Mays L.) emergence and production
}

\author{
Gabor MILICS ${ }^{1}$-Viliam NAGY ${ }^{2}$-Tomas ORFANUS ${ }^{2}$ - Lubomir LICHNER ${ }^{2}$ - \\ Peter SURDA ${ }^{2}$ \\ 1: Széchenyi István University, Faculty of Agricultural and Food Sciences, Department of Biosystems and Food \\ Engineering, Vár 2., 9200 Mosonmagyaróvár, Hungary; E-mail: milics.gabor@sze.hu \\ 2: Institute of Hydrology, Slovak Academy of Sciences, Dúbravská cesta 9, SK-841 04, Bratislava, Slovakia; \\ E-mail: nagy@uh.savba.sk
}

Keywords: Soil moisture content, maize emergence, maize yield

\section{Introduction}

In agriculture - especially in crop production - the state of soil moisture content in the topsoil is crucial, as the roots of most plants take up the water in this soil horizon (Neményi et al. 2008; Lehoczky et al. 2016). The most reliable method of soil moisture content measurement is manual sampling and laboratory analysis; however, this is time consuming and labour intensive. Other techniques used to measure moisture content in real time such as TDR sensors present difficulties (Nagy et al. 2008).

In most cases - due to their low spatial frequencies - manual sampling and laboratory analysis does not provide enough information for mapping within-field differences. Soil apparent electrical conductivity (ECa) measurements provide reliable information of spatial distribution of soil moisture content (Nagy et al., 2013, Milics et al., 2017). In agriculture - especially in precision agriculture - yield is the indicator of success. For this reason, factors influencing yield such as soil moisture content is in the focus of research, especially with sensors able to provide information about within-field differences. The nost up-to-date data collection method is based on UAV image collection. Images indicate different states of the soil until it is covered by vegetation.

\section{Materials and methods}

Measurements were carried out in the 23.52 hectare experimental study field of the Institute of Biosystems and Food Engineering, Faculty of Agricultural and Food Sciences, Széchenyi István University in the vicinity of Mosonmagyaróvár, Hungary [N47 $\left.54^{\prime} 20.00^{\prime \prime} ; \mathrm{E} 17^{\circ} 15^{\prime} 10.00^{\prime \prime}\right]$. The study field is an agricultural land - alluvial plain of the Leitha River - on which precision agriculture has been applied since 2001. The field is divided into smaller treatment units according to the requirement of precision agricultural technology.

The field cannot be characterized by one typical soil profile, as a buried riverbed (former Leitha) crosses it. Depending on the location, loam, silty loam and sandy loam appear on the field.

Yield map is collected every year by means of a Claas combine harvester equipped with yield mapping system. In 2018 monitoring was carried out by means of DJI Phantom Professional 3 UAV system equipped by a regular RGB camera. Moisture content differences were visible on the image, during emergence as well as the whole season. 


\section{Results and discussion}

Similarly to the yield map collected in 2017 , higher and lower potential places were visible on the UAV image. Yield map in 2018 showed similar high and low yielding area to the 2017 areas.
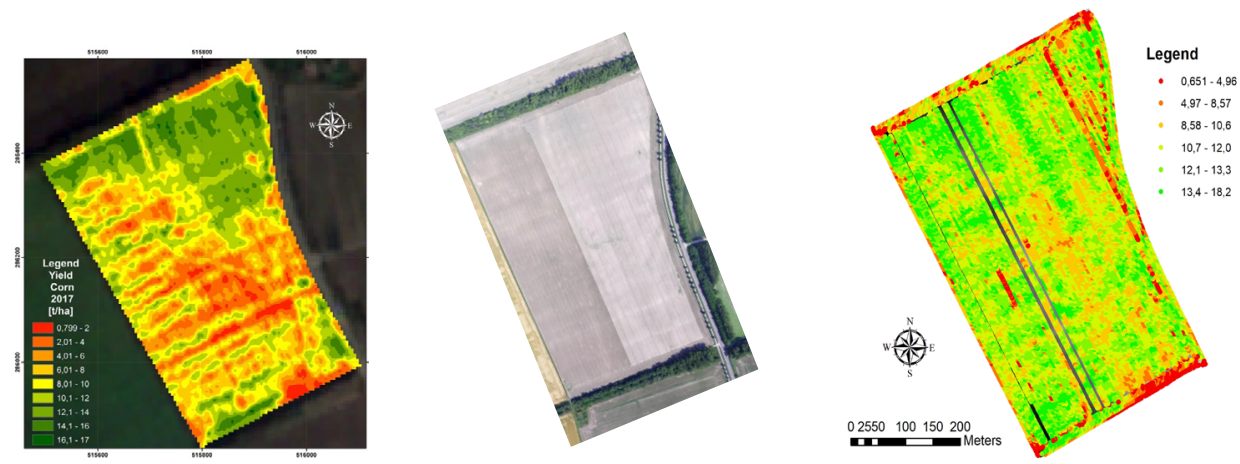

Figures: Yield map (maize) in 2017 and UAV image on 31.05. 2018 and yield map (maize) in 2018

\section{Conclusions}

Soil moisture content during emergence plays an important role on further development of maize plants and yielding. Moisture content differences has to be measured and monitored in the given field as well as monitoring of the soil moisture content has to be carried out in the next season when maize is going to be grown.

\section{Acknowledgement}

This project was supported by the EFOP-3.6.3-VEKOP-16-2017-00008 project. The project is co-financed by the European Union and the European Social Fund. This paper is also supported by VEGA and APVV projects.

This contribution was supported by the Scientific Grant Agency VEGA Project No. 2/0096/19 and Project APVV-15-0160.

\section{References}

Lehoczky É., Kamuti M., Mazsu N. \& Sándor R. 2016. Changes to soil water content and biomass yield under combined maize and maize-weed vegetation with different fertilization treatments in loam soil. J. Hydrol. Hydromech. 64: 150-159.

Milics, G., Kovács, A., Pörneczi, A., Nyéki A.,Varga Z., V, Nagy, L'. Lichner, Németh T., Baranyai G., Neményi M. (2017). Soil moisture distribution mapping in topsoil and its effect on maize yield. Biologia, 72(8), pp. 847-853. Retrieved 31 Dec. 2018, from doi:10.1515/biolog-2017-0100

Nagy V., Stekauerova V., Milics G., Lichner L. \& Nemenyi M. 2008. Harmonisation of different measuring methods of soil moisture used in Zitny Ostrov (SK) and Szigetkoz (HU). Cereal Research Communications 36: 1475-1478.

Nagy V., Milics G., Smuk N., Kovács A., Balla, I., Jolánkai M., Deákvári J., Szalay K., Fenyvesi L., Štekauerová V., Wilhelm Z., Rajkai K., Németh T., Neményi M. 2013. Continuous field soil moisture content mapping by means of apparent electrical conductivity (ECa) measurement. J. Hydrol. Hydromech. 61: 305-312.

Nemenyi M., Nagy V. \& Stekauerova V. 2008. Limiting factors of precision farming - soil compaction and precipitation. Cereal Research Communications 36: 1859-1862. 